Original Article

\title{
Perinatal exposure to a high-fat diet alters proopiomelanocortin, neuropeptide $Y$ and dopaminergic receptors gene expression and the food preference in offspring adult rats
}

\author{
Exposição perinatal a uma dieta hiperlipídica altera a expressão gênica de \\ proopiomelanocortina, neuropepitídeo Y e receptores dopaminérgicos e a preferência \\ alimentar em ratos adultos descendentes
}

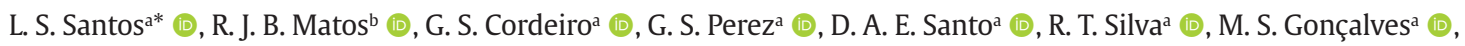 \\ G. T. Boaventurac (D, T. C. B. J. Deiróa (i) and J. M. Barreto-Medeiros ${ }^{a}$ (i) \\ aUniversidade Federal da Bahia - UFBA, Programa de Pós-Graduação em Alimentos, Nutrição e Saúde, Salvador, BA, Brasil \\ bUniversidade Federal de Pernambuco - UFPE, Centro Acadêmico de Vitória de Santo Antão, Núcleo de Educação Física e Ciências do Esporte, \\ Recife, PE, Brasil \\ cUniversidade Federal Fluminense - UFF, Departamento de Nutrição e Dietética, Niterói, RJ, Brasil
}

\begin{abstract}
Exposure to the hight-fat diet may alter the control of food intake promoting hyperphagia and obesity. The objective of this study was to investigate the effects of this diet on dopamine receptors ( $d r d 1$ and $d r d 2$ ), proopiomelanocortin (pomc), neuropeptideY (npy) genes expression, and preference food in adult rats. Wistar female rats were fed a hight-fat or control diet during pregnancy and lactation. The offspring were allocated into groups: Lactation Control (C) and High-fat (H). Post-weaning - Control Control (CC), offspring of mothers C, fed a control diet after weaning; Control Hight-fat ( $\mathrm{CH}$ ), offspring of mothers C, fed a hight-fat diet after weaning; Hight-fat Control (HC), offspring of mothers $\mathrm{H}$, fed with control diet after weaning; and Hight-fat Hight-fat $(\mathrm{HH})$, offspring of mothers $\mathrm{H}$, fed a $\mathrm{H}$ diet after weaning. The groups $\mathrm{CH}$ and $\mathrm{HH}$ presented greater expression of $d r d 1$ in comparison to the CC. The $d r d 2$ of $\mathrm{CH}$ and HC presented higher gene expression than did CC. HH presented higher pomc expression in comparison to the other groups. $\mathrm{HC}$ also presented greater expression in comparison to $\mathrm{CH}$. The npy of $\mathrm{HH}$ presented greater expression in relation to $\mathrm{CH}$ and $\mathrm{HC}$. HH and $\mathrm{HC}$ have had a higher preference for a high-fat diet at $102^{\circ}$ life's day. The high-fat diet altered the gene expression of the $d r d 1, d r d 2$, pomc and npy, and influencing the food preference for high-fat diet.
\end{abstract}

Keywords: critical period of development, hypothalamus, nucleus accumbens, obesogenic diet.

\begin{abstract}
Resumo
A exposição à dieta hiperlipídica pode alterar o controle da ingestão de alimentos, promovendo hiperfagia e obesidade. $\mathrm{O}$ objetivo deste estudo foi investigar os efeitos dessa dieta sobre a expressão gênica dos receptores de dopamina ( $d r d 1$ e $d r d 2$ ), da proopiomelanocortina (pomc) e neuropeptídeo Y (npy), e preferência alimentar em ratos adultos. Ratas Wistar foram alimentadas com uma dieta hiperlipídica ou controle durante a gestação e lactação. Os descendentes foram alocados em grupos: Lactação - Controle (C) e Hiperlipídica (H). Pós-desmame - Controle Controle (CC), descendentes das genitoras do grupo controle e alimentados com dieta controle após o desmame; Controle Hiperlipídica $(\mathrm{CH})$, descendentes das genitoras do grupo controle e alimentados com dieta hiperlipídica após o desmame; Hiperlipídica Controle (HC), descendentes das genitoras do grupo hiperlipídica e alimentados com dieta controle após o desmame; Hiperlipídica Hiperlipídica (HH), descendentes das genitoras do grupo hiperlipídica e alimentados com dieta hiperlipídica após o desmame. Os grupos $\mathrm{CH}$ e HH apresentaram maior expressão de $d r d 1$ em comparação ao CC. O drd2 de CH e HC apresentou maior expressão gênica que o CC. HH apresentou maior expressão de pomc em comparação com os outros grupos. O HC também apresentou maior expressão de pomc em comparação ao $\mathrm{CH}$. $\mathrm{O}$ npy do $\mathrm{HH}$ apresentou maior expressão em relação ao $\mathrm{CH}$ e $\mathrm{HC}$. $\mathrm{HH}$ e HC tiveram uma preferência maior por uma dieta rica em gordura no $102^{\circ}$ dia de vida. A dieta hiperlipídica alterou a expressão gênica dos $d r d 1, d r d 2$, pomc e npy e influenciou na preferência alimentar pela dieta hiperlipídica.
\end{abstract}

Palavras-chave: período crítico de desenvolvimento, hipotálamo, núcleo accumbens, dieta obesogênica.

*e-mail: meirenut.ssa@gmail.com

Received: March 8, 2020 - Accepted: June 28, 2020 


\section{Introduction}

The intake of a high-fat diet, especially during critical periods of development (gestation and lactation), has been extensively investigated in experimental research (Perez et al., 2015; Lima et al., 2018; Santos et al., 2018). Excessive intake this diet can alter physiology by promoting hyperphagia and, consequently, lead to an obesity phenotype (Ong and Muhlhausler, 2011).

Hyperphagia is a consequence of alters of the food intake control mechanism, which is complex and involves the hedonic system, modulated, among other neurotransmission pathways, by structures of the mesolimbic region (Volkow et al., 2011). The control of food intake is also performed by the homeostatic system, which has the hypothalamus as the central structure (Williams et al., 2000). These circuits involve neurons that express genes for the functionality of this control, as dopamine receptor genes (South et al., 2012), of proopiomelanocortin (pomc) and the neuropeptide $Y$ (npy) (Williams et al., 2000).

Physiologically, npy and pomc concentrations are related to the need for food intake and the need to suppress appetite, respectively. However, in obese individuals the npy concentration may be increased even when there is no need for caloric intake (Clark et al., 1984). Obesity and the high-fat diet, cafeteria-type, have also been associated with decreased dopamine receptor $d r d 2$ activity and binge eating (Johnson and Kenny, 2010). In an experimental study, it was evidenced that rats that consumed a cafeteria diet had a lower $d r d 2$ receptor concentration, in a brain region known the striated complex, when compared to lean rats that were not exposed to the cafeteria diet (Johnson and Kenny, 2010).

Experimental studies show that the exposure to a greater supply of fats and sugars in the uterus is one of the mechanisms underlying changes in food intake signaling and the preference for food sources of fat, sucrose and calories in adult life (Teegarden et al., 2009; Gugusheff et al., 2013). Evidence from a clinical study, in 2010, showed that this phenomenon may also occur in humans when reporting that the food preference of children for palatable foods may be a consequence of maternal food intake (Brion et al., 2010).

The effects of high-fat diets in the mentioned mechanisms are not yet fully elucidated, and even more scarce are the long term studies investigating the molecular effects of the consumption of high-fat diet on the hedonic and homeostatic control simultaneously. The diets used in most researches have a high lipid content, which does not represent human food consumption. The high-fat diet used in this research has 23\% lipids and ingredients that are part of the eating habits of a large part of the Western population, such as chocolate and biscuit.

Therefore, the aim of the present study was to investigate the effects of exposure to a fetal and/or post-weaning high-fat diet on the $d r d 1$ and $d r d 2$ dopamine receptors, pomc and npy genes expression and preference food in adult rats. Our hypothesis is that exposure to the highfat diet in the fetal and post weaning period increases the gene expression of $d r d 1$ and $n p y$, and decreases the expression of $d r d 2$ and pomc, contributing to hyperphagia and preference for a high-fat diet in adult rats.

\section{Material and Methods}

\subsection{Animals and treatment}

The management and care of animals followed the recommendations of the Brazilian Society of Laboratory Animal Science (SBCAL) and all experiments performed on animals were done according to Animal Research: Reporting of in Vivo Experiments guidelines. The animals received commercial (control) or high-fat diet and were kept under the same temperature conditions $\left(23 \pm 2{ }^{\circ} \mathrm{C}\right)$, light/dark cycle of 12 hours throughout life.

Female nulliparous wistar rats, aged 90-100 days and weighing $220 \mathrm{~g}$ and $280 \mathrm{~g}$, were used for mating with males of the same species. After detection of spermatozoa in the vaginal secretion, the pregnancy state was diagnosed.

The study was approved by the Ethics Committee on Animal Experimentation, according to protocol $n^{\circ} 02 / 13$, of the Federal University of Bahia.

\subsection{Experimental groups}

The day after birth, the litters were standardized to 8 pups, which were kept with the lactating mothers until day 21 , when they were weaned. Male offspring $C$ of the group GC (mothers fed a control diet during pregnancy and lactation) and male offspring $\mathrm{H}$ of the group $\mathrm{GH}$ (mothers fed a high-fat diet during pregnancy and lactation) were subdivided according to a diet offered after weaning. The animals were divided in experimental groups according to the diet consumed (see Table 1 ). After weaning, these animals were housed in polypropylene boxes until the period of the study of food consumption, when they were housed in metabolic cages.

\subsection{Body weight}

The animals were weighed in the 2nd and 120th life's day. The animals were weighed between 8 and $11 \mathrm{am}$, values are presented as mean + SEM. Was used digital electronic scale - Marte, model S-4000, with a capacity of $4 \mathrm{~kg}$ and sensitivity of $0.001 \mathrm{~g}$.

\subsection{Diets}

The control diet consisted of a standard diet commercial for rats (Nuvilab® CR1), containing approximately $22 \%$ protein, $57 \%$ carbohydrate, $4 \%$ lipids, totaling approximately $3.5 \mathrm{kcal} / \mathrm{g}$. The high-fat diet consisted of commercial ration (Nuvilab®), roasted peanuts, milk chocolate and biscuit (Estadella et al., 2004), presenting in 100g: 46\% carbohydrate, $17 \%$ protein, $23 \%$ lipids and approximately $4.5 \mathrm{kcal} / \mathrm{g}$. A table with analysis of the composition of fatty acids of the two diets used in the present study was published by Oliveira et al. (2011).

\subsection{Food preference}

After 10 day of adaptation to the metabolic cage, the high-fat and control diets were offered simultaneously, 
Table 1. Experimental design. The rats were fed commercial standard diet for rodents control diet or high-fat diet during pregnancy, lactation and post-weaning (up to 100 days of life). During the feeding period, rats consumed both diets (control diet and high-fat diet). The numbers in parentheses indicate the animals number in each nutritional group.

\begin{tabular}{|c|c|c|c|c|c|}
\hline \multicolumn{6}{|c|}{ Experimental Design } \\
\hline Genitors (n) & $\begin{array}{c}\text { Gestation and } \\
\text { lactation }\end{array}$ & $\begin{array}{l}\text { Offspring during } \\
\text { lactation (n) }\end{array}$ & Offspring (n) & $\begin{array}{c}\text { Post-weaning } \\
\left(21-100^{\circ} \text { life's day }\right)\end{array}$ & $\begin{array}{c}\text { Food preference } \\
\left(102-116^{\circ} \text { life's }\right. \\
\text { day })\end{array}$ \\
\hline \multirow{5}{*}{$\mathrm{GC}(5)$} & \multirow{5}{*}{ Control diet } & \multirow{5}{*}{$C(23)$} & \multirow[t]{2}{*}{ CC (12) } & \multirow[t]{2}{*}{ Control diet } & Control diet \\
\hline & & & & & High-fat diet \\
\hline & & & \multirow[t]{2}{*}{$\mathrm{CH}(11)$} & \multirow[t]{2}{*}{ High-fat diet } & Control diet \\
\hline & & & & & High-fat diet \\
\hline & & & \multirow[t]{2}{*}{$\mathrm{HC}(11)$} & \multirow[t]{2}{*}{ Control diet } & Control diet \\
\hline & & & & & High-fat diet \\
\hline \multirow[t]{2}{*}{$\mathrm{GH}(5)$} & \multirow[t]{2}{*}{ High-fat diet } & \multirow[t]{2}{*}{$\mathrm{H}(23)$} & \multirow[t]{2}{*}{$\mathrm{HH}(12)$} & \multirow[t]{2}{*}{ High-fat diet } & Control diet \\
\hline & & & & & High-fat diet \\
\hline
\end{tabular}

in separate containers, in the same amount (70g) (Ong and Muhlhausler, 2011). The food intake of each diet was evaluated every 48 hours on days $102^{\circ}, 110^{\circ}$ and $116^{\circ}$. The relative food consumption in grams was investigated using the next formula: (food intake ( $\mathrm{g}$ )/100 g body weight).

\subsection{Isolation of the hypothalamus and nucleus accumbens}

On the 120th day of life, the animals of all groups were euthanized at 7:00 a.m, after 12 hours of fasting. After decapitation, a craniotomy was performed for dissection of the brain and then isolation of the hypothalamus (Glowinski and Iversen, 1996) and nucleus accumbens (Ong and Muhlhausler, 2011) in labeled microtubo (Eppendorf®), frozen in solid carbon dioxide (dry ice) and then stored in a freezer at $-80{ }^{\circ} \mathrm{C}$ the preparation of the samples for real-time PCR analysis (Galindo et al., 2015).

\subsection{Real-time PCR}

The PCR reaction was performed using the SYBR® Green PCR Master Mix (Qiagen ${ }^{\circledR}$ ) and analyzed in realtime through an automated sequence detection system called Rotor-Gene® TM RG 3000 (Corbett Life Science, Australia) to determine the mRNA expression of the samples. The total reaction volume was $25 \mu \mathrm{L}$, including $12.5 \mu \mathrm{L}$ of the fluorescent compound SYBR Green PCR Master Mix (Qiagen ${ }^{\circledR}$ ), $2 \mu \mathrm{L}$ of cDNA (used as template for the reaction), $2.5 \mu \mathrm{L}$ of the first sense and anti-sense and $5.5 \mu \mathrm{L}$ of RNase-free water. Reactions were incubated at $95^{\circ} \mathrm{C}$ for 5 minutes to activate DNA polymerase, followed by 40 cycles of 5 seconds at $95^{\circ} \mathrm{C}$ for denaturation and 10 seconds at $60{ }^{\circ} \mathrm{C}$ for extension and collection of the fluorescent. The sequence of primers used to amplify were as follows: $\beta$-actina - forward: 5'- ACG GTC AGG TCA TCA CTA TCG-3 ' and reverse: 5'- CAG CAC TGT GTT GGC ATA GAG-3’; drd1a - forward: 5 'CTG GAG GAC ACC GAG GAT GAC-3' and reverse: 5'- GTC GAT GAG GGA CGA TGA AAT GG -3 '; drd2 - forward: 5'- CAA CAA TAC AGG CAA CAC AGA ATG AG-3 'and reverse: 5'- ACC AGC AGA GTG ACG ATG AAG G-3 ‘; pomc - forward: 5'- GAGGTTAAGGAGCAGTGACTAAGA -3’ and reverse: 5'- GTAGCAGAATCTCGGCATCTTCC -3'; npy - forward: 5'- GTGGACTGACCCTCGCTCTATC -3' and reverse: 5'- ATGAGATTGATGTAGTGTCGCAGA -3'. The primers were synthesized and purified by IDT - Integrated DNA Technologies (USA). The relative value of the expression levels of dopamine $d r d 1 \mathrm{a}$ and $d r d 2$ receptor mRNAs in the nucleus accumbens and of the pomc and npy in the hypothalamus were calculated using the $\mathrm{Ct}$ (threshold cycle) method (Livak and Schmittgen, 2001). $\beta$-actin as a gene for normalization. The Formula 1 used to calculate the relative value of expression levels in the sample and normalize with the endogenous reference level ( $\beta$-actin) was as follows:

\section{$2-\Delta \Delta C T$}

$\Delta \mathrm{CT}=$ difference between the $\mathrm{CT}$ of the gene of interest and the $\beta$-actin; $\Delta \Delta \mathrm{CT}$ for sample $=$ mean of $\Delta \mathrm{CT}$ of the experimental group sample, less the mean of the $\Delta C T$ of the control group sample (used as a parameter for calibration) (Pinheiro et al., 2019).

\subsection{Statistical analyzes}

The data were analyzed in the program Statistica 7.0 and Graph Pad Prism version 6.04. Two-way ANOVA was used. The experimental design is a standard 2-factor design, with factor A being the dam's diet and consisting of 2 levels (control diet or hight-fat diet) and factor $B$ being the offspring food environment consisting of 2 levels (control diet or hight-fat diet). When ANOVA indicated difference, the Bonferroni test was used to identify differences between groups. Statistical significance was considered assuming a $5 \%$ level in all cases.

\section{Results}

\subsection{Dopamine receptors drd1 and drd2 gene expression in} the nucleus accumbens

The groups exposed to high-fat diet after weaning had $d r d 1$ receptor expression 4 times higher when compared 
to the control group (mean \pm SEM) (CC: $1.0 \pm 0.1, n=5$; $\mathrm{CH}: 3,9 \pm 0.4, \mathrm{n}=5$; HC: $2.8 \pm 1.3, \mathrm{n}=5$; $\mathrm{HH}: 3.9 \pm 0.4$, $\mathrm{n}=5$ ). However, in relation to the $d r d 2$ receptor, the $\mathrm{CH}$ and $\mathrm{HC}$ groups presented approximately 3 times higher gene expression in the nucleus accumbens compared to the CC group (mean \pm SEM) (CC: $1.0 \pm 0.1, \mathrm{n}=5$; $\mathrm{CH}: 3.1$ $\pm 0.4, n=5$; HC: $3.3 \pm 0.5, n=5 ; \mathrm{HH}: 2.4 \pm 0.6, n=5$ ) (see Figure $1 \mathrm{~A}$ and $1 \mathrm{~B})$.

\subsection{Pomc and npy gene expression in the hypothalamus}

$\mathrm{HH}$ group presented greater pomc expression compared to the other groups. The HC group also had a higher expression when compared to the $\mathrm{CH}$ group (mean \pm SEM) (CC: $1.0 \pm$ $0.3, \mathrm{n}=5$; $\mathrm{CH}: 0.6 \pm 0.1, \mathrm{n}=5$; HC: $1.4 \pm 0.3, \mathrm{n}=5$; HH: $2.1 \pm$ $0.4, \mathrm{n}=5$ ). Regarding $n p y$, the HH group presented greater expression in relation to the $\mathrm{CH}$ and $\mathrm{HC}$ groups (mean \pm SEM) (CC: $1.0 \pm 0.1, n=5 ; \mathrm{CH}: 0.7 \pm 0.0, n=5 ; \mathrm{HC}: 0.8 \pm 0.0$, $\mathrm{n}=5 ; \mathrm{HH}: 1.2 \pm 0.0, \mathrm{n}=5$ ) (see Figure $2 \mathrm{~A}$ and $2 \mathrm{~B}$ ).

(A)

DRD1

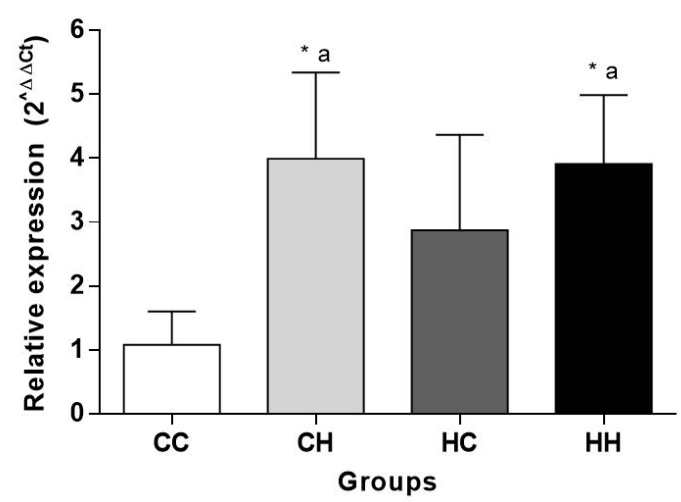

\subsection{Food preference}

The progenitors's offspring who consumed high-fat diet in the perinatal period had a higher preference for food high-fat diet on the 102nd day (Relative intake of high-fat diet (mean \pm SEM) $(\mathrm{CC}: 12.6 \pm 0.6, \mathrm{n}=12 ; \mathrm{CH}: 12.8 \pm 0.6$, $\mathrm{n}=11 ; \mathrm{HC}: 16.7 \pm 1.1, \mathrm{n}=11 ; \mathrm{HH}: 15.3 \pm 0.7, \mathrm{n}=12$ ) (see Table 2). Regarding the control diet intake during the study of food preference, the groups showed no difference (see Table 2).

\subsection{Body weight}

On the second day of life, there was no difference in the animals' body weight diet (mean \pm SEM) (C: $6.8 \pm 0.1$, $\mathrm{n}=23 ; \mathrm{H}: 6.9 \pm 0.1, \mathrm{n}=23$ ) (see Figure 3 ). However, on the 120th day the $\mathrm{HC}$ and $\mathrm{HH}$ animals had greater weight compared to the CC group (mean \pm SEM) (CC: $321,5 \pm$ 5.6, $n=12 ; C H: 335.9 \pm 6.0, n=11 ; H C: 359.1 \pm 10.7, n=11$; $\mathrm{HH}: 364.9 \pm 9.7, \mathrm{n}=12$ ) (see Figure 4).

Figure 1. Drd1 (A) and $d r d 2$ (B) gene expression in the nucleus accumbens of offspring exposed or not to a control diet or high-fat diet during perinatal and/or postnatal period. Values are presented as mean \pm SEM using two-way ANOVA followed by the Bonferroni multiplecomparison test. Level of significance: "p< 0,05; "a": compared to CC, "b": compared to CH; "c": compared to HC; "d": compared to HH.

(A)

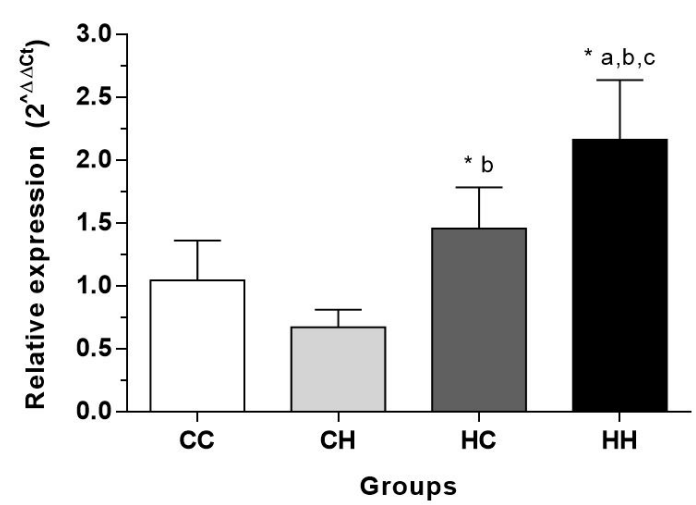

(B)

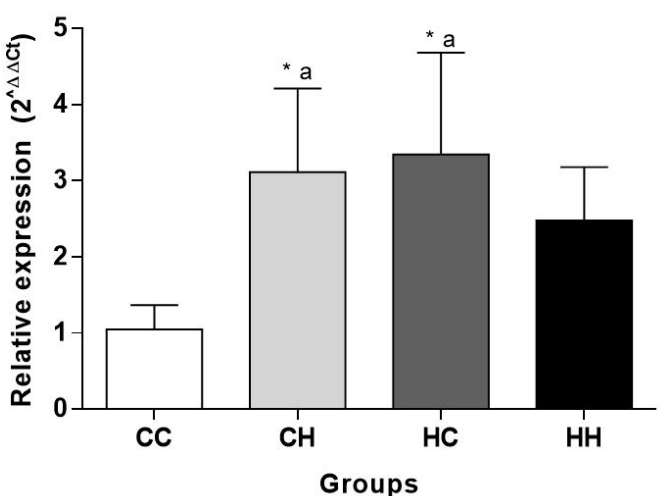

Figure 2. Pomc (A) and npy (B) gene expression in the hypothalamus of offspring exposed or not to a control diet or high-fat diet during perinatal and/or postnatal period. Values are presented as mean \pm SEM using two-way ANOVA followed by the Bonferroni multiplecomparison test. Level of significance: *p<0,05; "a": compared to CC, "b": compared to CH; "c": compared to HC; "d": compared to HH. 
Table 2. Relative food intake of the high-fat diet and control diet during the food preference study in offspring exposed or not a control diet or high-fat diet during perinatal and/or postnatal period.

\begin{tabular}{|c|c|c|c|}
\hline \multicolumn{4}{|c|}{ High-fat diet ( $g / 100 \mathrm{~g}$ body weight) } \\
\hline & $102^{\circ}$ day & $110^{\circ}$ day & $116^{0}$ day \\
\hline$C C$ & $12.6 \pm 0.6$ & $11.3 \pm 0.2$ & $11.1 \pm 0.7$ \\
\hline $\mathrm{CH}$ & $12.8 \pm 0.6$ & $12.4 \pm 0.3$ & $11.4 \pm 0.4$ \\
\hline HC & $16.7 \pm 1.1^{\text {a.b* }}$ & $13.7 \pm 0.9$ & $10.0 \pm 0.5$ \\
\hline$H H$ & $15.3 \pm 0.7^{\text {a.b }}$ & $11.7 \pm 0.9$ & $10.7 \pm 0.5$ \\
\hline \multicolumn{4}{|c|}{ Control diet (g/100 g body weight) } \\
\hline & $102^{\circ}$ day & $110^{\circ}$ day & $116^{0}$ day \\
\hline$C C$ & $1.4 \pm 0.2$ & $1.1 \pm 0.1$ & $1.1 \pm 0.3$ \\
\hline $\mathrm{CH}$ & $2.1 \pm 0.2$ & $1.5 \pm 0.3$ & $0.9 \pm 0.1$ \\
\hline HC & $1.8 \pm 0.2$ & $1.0 \pm 0.3$ & $1.0 \pm 0.3$ \\
\hline$H H$ & $1.9 \pm 0.2$ & $1.1 \pm 0.2$ & $0.7 \pm 0.1$ \\
\hline
\end{tabular}

Values are presented as mean + SEM using two-way ANOVA followed by the Bonferroni multiple-comparison test. * $\mathrm{p}<0,005$; "a": compared to CC, "b": compared to CH; "c": compared to HC; "d": compared to HH.

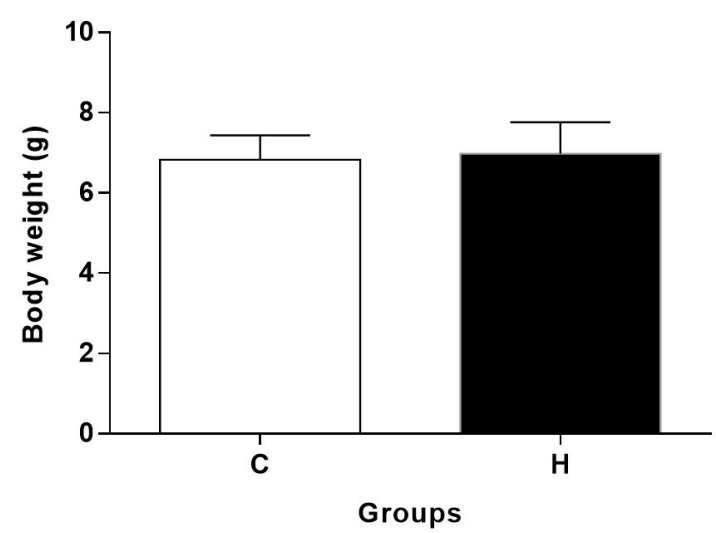

Figure 3. Body weight on the second day life's of offspring from mothers submitted the control diet (C) or the high-fat diet $(\mathrm{H})$. Values are presented as mean + SEM using Student t-test. C: $\mathrm{n}=23$; $\mathrm{H}: \mathrm{n}=23$.

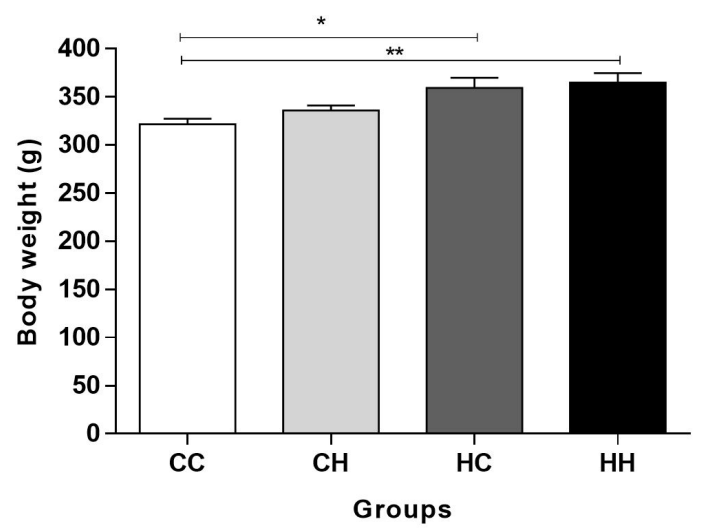

Figure 4. Body weight on the 120th offspring from mothers submitted the control diet or the high-fat diet. Values are presented as mean \pm SEM using two-way ANOVA followed by the Bonferroni multiple-comparison test. ${ }^{*} \mathrm{p}<0,05 ;{ }^{* *} \mathrm{p}<0,005$.

\section{Discussion}

The high-fat diet was able to influence the gene expression of dopaminergic receptors ( $d r d 1$ and $d r d 2$ ) in the nucleus accumbens, altering the hedonic pathway of food behavior. This result may be related to the increase in the release of dopamine, caused by the high consumption of fat and sucrose (Liang et al., 2006; Rada et al., 2005).

South et al., in 2012, showed that rats fed with standard diet for 16 weeks and later fed for 9 days on a highly palatable diet had higher $d r d 1$ and $d r d 2$ receptor expression (South et al., 2012). As Ong et al. (2013), it was shown that male rats consuming a cafeteria diet for 8 weeks had higher expression of dopamine $d r d 1$ receptor mRNA compared to animals that consumed a standard diet. However, when they looked at dopamine receptor ( $d r d 2$ ) expression, they found no difference (Ong et al., 2013). In this study was evidenced that the exposure to the high-fat diet was able to increase the $d r d 1$ expression in the animals exposed to the high-fat diet in the after weaning and in the all life, this diet increased too the $d r d 2$ receptor gene expression, even when there was a shift to a more balanced diet. The difference in expression of the $d r d 1$ and $d r d 2$ receptors between the experimental groups in this study may be related to the specific function of these receptors. It is known that while $d r d 1$ is related to motivation for the search for food (Nair et al., 2011), drd2 is related to satiety (Juárez et al., 2010). The group exposed to the high-fat diet only in the perinatal period showed a greater expression of $d r d 2$, however, it was one of the groups with the highest preference for on the high-fat diet. This result may be a physiological action aiming at favoring the increase of satiety in animals with molecular predisposition to the preference for the high-fat diet. The group exposed to a high-fat diet throughout life showed similar drd2 expression to the control group. This result suggests a phenotypic adaptation of the animals of this group considering that they were always exposed to high- fat diet. 
The increase in the expression of dopamine receptors suggests an increase in the responsiveness to this neurotransmitter; however, this response is also dependent on other factors, such as receptor sensitivity, which may reduce the reaction to dopamine and trigger a reverse effect (Geiger et al., 2009). This state of decreased dopaminergic activity was evidenced by Davis et al. (2008) in a study which rats fed a high-fat diet in adult life had lower turnover of dopamine confirming a state of less activity of this neurotransmitter (Davis et al., 2008).

In the present study, the high-fat diet was also able to alter one of the homeostatic signaling pathways related to food intake. Exposure to the high-fat diet only in the perinatal period promoted greater expression of the pomc gene compared to exposure to the high-fat diet after weaning. This effect was exacerbated when the exposure to the high-fat diet occurred from the perinatal period to adult life. Similar results were found by Chen et al. (2009). They showed that offspring of mothers who consumed a high-fat diet during lactation presented greater pomc expression at 126 days after birth, suggesting an adaptive response of the offspring to an obesogenic environment (Chen et al., 2009).

npy gene expression decreased in animals that were exposed to the high-fat diet, except in those that were exposed both in the perinatal period and in the period after weaning, which had npy gene expression similar to the expression in the animals exposed to the control diet. It is known that npy stimulates the alimentary behavior being an orexigenic peptide (Morris et al., 2007). Its activity is neutralized by pomc to inhibit diet and promote homeostasis (Myers Junior et al., 2009). In a study conducted in 2015, Sanchez-Hernandez et al. (2015) showed greater npy gene expression 14 days after weaning in offspring exposed to a high-fat diet and fat soluble vitamins in the gestational period. However, in another study with a highfat diet, it was observed a decrease in this neuropeptide, which suggests an attempt to restore the energy balance of these animals (Morris et al., 2007).

The mechanism to understand how fat can alter the expression of food consumption regulation peptides is not all clear. A possible modulating mechanism of pomc and npy expression is through the action of the hormones leptin and insulin (Bouret et al., 2004). It is suggested that these hormones cross the blood-brain barrier to interact with specific receptors present on the pomc and npy neurons (Myers Junior et al., 2009; Patterson et al., 2011), allowing greater pomc expression and decreased npy expression through a signaling cascade in the cytoplasm and nucleus of neural cells (Kitamura et al., 2006).

In the present study, the animals exposed to the high-fat diet in the perinatal period and the animals that maintained the intake until the adult life presented higher body weight on the last day of life and higher food preference for the high-fat diet. However, the food preference significant only the first day the study (102nd day), suggests that these animals adapted to diet in the later days. Corroborating with the result, Vucetic and collaborators investigated a diet in mice (C57BL/6J) exposed to a high-fat diet (60\% of lipids) during gestation and lactation and showed that the animals presented food preference for the high-fat diet (Vucetic et al., 2010). Gugusheff and collaborators investigating the food preference of wistar rats for 6 weeks also found a similar result (Gugusheff et al., 2013).

Studies show that diets rich in fat and sugar activate neural mechanisms, more specifically the mesolimbic reward system, favoring the release of dopamine and triggering sensation of pleasure followed by the motivation to consume them even without hunger and in situations where it is possible to choose for a less fatty and less sugary food (Gugusheff et al., 2013; Vucetic et al., 2010). The results shown in this study suggest that dietary preference was altered in animals that were exposed to the hig-fat diet at an early stage, even when at weaning they started to consume a nutritionally balanced diet, confirming that nutritional injury during critical periods of development can promote changes in long term, even when the offending factor is eliminated.

In conclusion, the results described here, show that the exposure to high-fat diet in the perinatal and post-weaning period altered the gene expression of the components of the hedonic control ( $d r d 1$ and $d r d 2$ dopamine receptors) and homeostatic control (pomc and npy) and food preference in rats. Thus, it was verified that the effects of the high-fat diet on the aspects studied can arise both at the molecular level and at the behavioral level. These results may be considered additional factors that explain why some individuals exposed to an obesogenic environment present hyperphagia and came to be obese and other individuals do not.

\section{Acknowledgements}

The present study was supported by CNPq (grant no. 481822/2013-5) and FAPESB.

\section{References}

BOURET, S.G., DRAPER, S.J. and SIMERLY, R.B., 2004. Trophic action of leptin on hypothalamic neurons that regulate feeding. Science, vol. 304, no. 5667, pp. 108-110. http://dx.doi.org/10.1126/ science.1095004. PMid:15064420.

BRION, M.J.A., NESS, A.R., ROGERS, I., EMMETT, P., CRIBB, V., DAVEY SMITH, G. and LAWLOR, D.A., 2010. Maternal macronutrient and energy intakes in pregnancy and offspring intake at 10 $\mathrm{y}$ : exploring parental comparisons and prenatal effects. The American Journal of Clinical Nutrition, vol. 91, no. 3, pp. 748-756. http://dx.doi.org/10.3945/ajcn.2009.28623. PMid:20053880.

CHEN, H., SIMAR, D. and MORRIS, M.J., 2009. Hypothalamic neuroendocrine circuitry is programmed by maternal obesity: interaction with postnatal nutritional environment. PLOS One, vol. 4, no. 7, e6259. http://dx.doi.org/10.1371/journal. pone.0006259. PMid:19606226.

CLARK, J.T., KALRA, P.S., CROWLEY, W.R. and KALRA, S.P., 1984. Neuropeptide $Y$ and human pancreatic polypeptide stimulate feeding behavior in rats. Endocrinology, vol. 115, no. 1, pp. 427429. http://dx.doi.org/10.1210/endo-115-1-427. PMid:6547387.

DAVIS, J.F., TRACY, A.L., SCHURDAK, J.D., TSCHÖP, M.H., LIPTON, J.W., CLEGG, D.J. and BENOIT, S.C., 2008. Exposure to elevated levels of dietary fat attenuates psychostimulant reward and mesolimbic dopamine turnover in the rat. Behavioral Neuroscience, vol. 
122, no. 6, pp. 1257-1263. http://dx.doi.org/10.1037/a0013111. PMid:19045945.

ESTADELLA, D., OYAMA, L.M., DÂMASO, A.R., RIBEIRO, E.B. and OLLER DO NASCIMENTO, C.M., 2004. Effect of palatable hyperlipidic diet on lipid metabolism of sedentary and exercised rats. Nutrition, vol. 20, no. 2, pp. 218-224. http://dx.doi.org/10.1016/j. nut.2003.10.008. PMid:14962690.

GALINDO, L.C., BARROS, M.D.A.L., PINHEIRO, I.L., SANTANA, R.V., MATOS, R.J., LEANDRO, C.G., SOUZA, S.L. and CASTRO, R.M., 2015. Neonatal serotonin reuptake inhibition reduces hypercaloric diet effects on fat mass and hypothalamic gene expression in adult rats. Neuroscience, vol. 46, pp. 76-81. PMid:26287581.

GEIGER, B.M., HABURCAK, M., AVENA, N.M., MOYER, M.C., HOEBEL, B.G. and POTHOS, E.N., 2009. Deficts of mesolimbic dopamine neurotransmission in rat dietary obesity. Neuroscience, vol. 159, no. 4, pp. 1193-1199. http://dx.doi.org/10.1016/j. neuroscience.2009.02.007. PMid:19409204.

GLOWINSKI, J. and IVERSEN, L.L., 1996. Regional studies of catecholamines in the rat brain-I.Journal of Neurochemistry, vol. 13, no. 8, pp. 655-669. http://dx.doi.org/10.1111/j.1471-4159.1966. tb09873.x. PMid:5950056.

GUGUSHEFF, J.R., VITHAYATHIL, M., ONG, Z.Y. and MUHLHAUSLER, B.S., 2013. The effects of prenatal exposure to a 'junk food' diet on offspring food preferences and fat deposition can be mitigated by improved nutrition during lactation. Journal of Developmental Origins of Health and Disease, vol. 4, no. 5, pp. 348-357. http://dx.doi.org/10.1017/S2040174413000330. PMid:24970728.

JOHNSON, P.M. and KENNY, P.J.K., 2010. Dopamine D2 receptors in addiction-like reward dysfunction and compulsive eating in obese rats. Nature Neuroscience, vol. 13, no. 5, pp. 635-641. http://dx.doi.org/10.1038/nn.2519. PMid:20348917.

JUÁREZ, J.G.T., DÍAZ, J.M.M., GARDUÑO, B.F. and PÉREZ, R.E.E., 2010. Los receptores dopaminérgicos D2/D3 hipotalámicos participan em la regulación del comportamiento alimentario. Mexican Journal of Behavior Analysis, vol. 36, no. 2, pp. 53-69. http://dx.doi.org/10.5514/rmac.v36.i2.18482.

KITAMURA, T., FENG, Y., KITAMURA, Y.I., CHUA JUNIOR, S.C.J.R., XU, A.W., BARSH, G.S., ROSSETTI, L. and ACCILI, D., 2006. Forkhead protein FoxO1 mediates Agrp-dependent effects of leptin on food intake. Nature Medicine, vol. 12, no. 5, pp. 534-540. http:// dx.doi.org/10.1038/nm1392. PMid:16604086.

LIANG, N.C., HAJNAL, A. and NORGREN, R., 2006. Sham feeding corn oil increases accumbens dop mine in the rat. American Journal of Physiology. Regulatory, Integrative and Comparative Physiology, vol. 291, no. 5, pp. R1236-R1239. http://dx.doi. org/10.1152/ajpregu.00226.2006. PMid:16763080.

LIMA, M.S., PEREZ, G.S., MORAIS, G.L., SANTOS, L.S., CORDEIRO, G.S., COUTO, R.D., DEIRÓ, T.C.B.J., LEANDRO, C.G. and BARRETOMEDEIROS, J.M., 2018. Effects of maternal high fat intake during pregnancy and lactation on total cholesterol and adipose tissue in neonatal rats. Brazilian Journal of Biology = Revista Brasileira de Biologia, vol. 78, no. 4, pp. 615-618. http://dx.doi. org/10.1590/1519-6984.166788. PMid:29319751.

LIVAK, J.K. and SCHMITTGEN, T.D., 2001. Analysis of relative gene expression data using realtime quantitative PCR and the 22DDCT method. Methods, vol. 25, no. 4, pp. 402-408. http://dx.doi. org/10.1006/meth.2001.1262. PMid:11846609.

MORRIS, M.J., GANNAN, E., STROUD, L.M., BECK-SICKINGER, A.G. and O'BRIEN, T.J., 2007. Neuropeptide Y suppresses absence seizures in a genetic rat model primarily through effects on $Y$ receptors. The European Journal of Neuroscience, vol. 25, no. 4, pp.
1136-1143. http://dx.doi.org/10.1111/j.1460-9568.2007.05348.x. PMid:17331209.

MYERS JUNIOR, M.G., MÜNZBERG, H., LEINNINGER, G.M. and LESHAN, R.L., 2009. The geometry of leptin action in the brain: more complicated than a simple ARC. Cell Metabolism, vol. 9, no. 2, pp. 117-123. http://dx.doi.org/10.1016/j.cmet.2008.12.001. PMid:19187770.

NAIR, S.G., NAVARRE, B.M., CIFANI, C., PICKENS, C.L., BOSSERT, J.M. and SHAHAM, Y., 2011. Role of dorsal medial prefrontal cortex dopamine $\mathrm{d} 1$-family receptors in relapse to high-fat food seeking induced by the anxiogenic drug yohimbine. Neuropsychopharmacol, vol. 36, no. 2, pp. 497-510. http://dx.doi. org/10.1038/npp.2010.181. PMid:20962767.

OLIVEIRA, T.W., LEANDRO, C.G., JESUS DEIRÓ, T.C., SANTOS PEREZ, G., FRANÇA SILVA, D., DRUZIAN, J.I., COUTO, R.D. and BARRETOMEDEIROS, J.M., 2011. A perinatal palatable high-fat diet increases food intake and promotes hypercholesterolemia in adult rats. Lipids, vol. 46, no. 11, pp. 1071-1074. http://dx.doi. org/10.1007/s11745-011-3604-7. PMid:21847693.

ONG, Z.I., WANASURIA, A.F., LIN, M.Z., HISCOCK, J. and MUHLHAUSLER, B.S., 2013. Chronic intake of a cafeteria diet and subsequent abstinence. Sex-specific effects on gene expression in the mesolimbic reward system. Appetite, vol. 65, pp. 189-199. http://dx.doi.org/10.1016/j.appet.2013.01.014. PMid:23402719.

ONG, Z.Y. and MUHLHAUSLER, B.S., 2011. Maternal "junk-food" feeding of rat dams alters food choices and development of the mesolimbic reward pathway in the offspring. The FASEB Journal, vol. 25, no. 7, pp. 2167-2179. http://dx.doi.org/10.1096/ fj.10-178392. PMid:21427213.

PATTERSON, C.M., LESHAN, R.L., JONES, J.C. and MYERS JUNIOR, M.G.J.R., 2011. Molecular mapping of mouse brain regions innervated by leptin receptor-expressing cells. Brain Research, vol. 1378, no. 10, pp. 18-28. http://dx.doi.org/10.1016/j. brainres.2011.01.010. PMid:21237139.

PEREZ, G.S., SANTOS, L.S., CORDEIRO, G.S., PARAGUASSÚ, G.M., ATHANAZIO, D.A., COUTO, R.D., DEIRÓ, T.C.B.J., CASTRO, R. M. and BARRETO-MEDEIROS, J.M., 2015. Maternal and post-weaning exposure to a high fat diet promotes visceral obesity and hepatic steatosis in adult rats. Nutrición Hospitalaria, vol. 32, no. 4, pp. 1653-1658. http://dx.doi.org/10.3305/nh.2015.32.4.9607. PMid:26545531.

PINHEIRO, I.L., SILVA, A.I., REGINATO, A., SILVA FILHO, R.C., GALINDO, L.C.M., MATOS RJ, B., FERRAZ, J.C.J.S., CASTRO, A.E.T.M.S., FERREIRA, M.M., CASTRO, R. M. and SOUZA, S.L., 2019. Neonatal fluoxetine exposure modulates serotonergic neurotransmission and disturb inhibitory action of serotonin on food intake. Behavioural Brain Research, vol. 357-358, no. 14, pp. 65-70. http://dx.doi.org/10.1016/j.bbr.2017.07.038. PMid:28756214.

RADA, P., AVENA, N.M. and HOEBEL, B.G., 2005. Daily bingeing on sugar repeatedly releases dopamine in the accumbens shell. Neuroscience, vol. 134, no. 3, pp. 737-744. http://dx.doi. org/10.1016/j.neuroscience.2005.04.043. PMid:15987666.

SANCHEZ-HERNANDEZ, D., POON, A.N., KUBANT, R., KIM, H., HUOT, P.S.P., CHO, C.E., PANNIA, E., PAUSOVA, Z. and ANDERSON, G.H., 2015. A gestational diet high in fat-soluble vitamins alters expression of genes in brain pathways and reduces sucrose preference, but not food intake in Wistar male rat offspring. Applied Physiology, Nutrition, and Metabolism, vol. 40, no. 4, pp. 424-431. http://dx.doi.org/10.1139/apnm-2014-0480. PMid:25787712.

SANTOS, L.S., CORDEIRO, G.S., PEREZ, G.S., SANTO, D.A.E., MACÊDO, A.P.A., LIMA, M.S., CARNEIRO, I.B.C., MACHADO, M.E.P.C., DEIRÓ, T.C.B.J. and BARRETO-MEDEIROS, J.M., 2018. Influence of mother nutrition during pregnancy and/or lactation on offspring food 
preference in experimental models. Brazilian Journal of Biology = Revista Brasileira de Biologia, vol. 79, no. 2, pp. 220-232. http://dx.doi.org/10.1590/1519-6984.179134. PMid:30156603.

SOUTH, T., WESTBROOK, F. and MORRIS, M.J., 2012. Neurological and stress related effects of shifting obese rats from a palatable diet to chow and lean rats from chow to a palatable diet. Physiology E Behavior, vol. 105, no. 4, pp. 1052-1057. http://dx.doi.org/10.1016/j.physbeh.2011.11.019. PMid:22155008.

TEEGARDEN, S.L., SCOTT, A.N. and BALE, T.L., 2009. Early life exposure to a high fat diet promotes long-term changes in dietary preferences and central reward signaling. Neuroscience, vol. 162, no. 4, pp. 924-932. http://dx.doi.org/10.1016/j. neuroscience.2009.05.029. PMid:19465087.
VOLKOW, N.D., WANG, G.J. and BALER, R.D., 2011. Reward, dopamine and the control of food intake: implications of obesity. Trends in Cognitive Sciences, vol. 15, no. 1, pp. 37-46. http://dx.doi. org/10.1016/j.tics.2010.11.001. PMid:21109477.

VUCETIC, Z., KIMMEL, J., TOTOKI, K., HOLLENBECK, E. and REYES, T.M., 2010. Maternal high-fat diet alters methylation and gene expression of dopamine and opioid-related genes. Endocrinology, vol. 151, no. 10, pp. 4756-4764. http://dx.doi.org/10.1210/ en.2010-0505. PMid:20685869.

WILLIAMS, G., HARROLD, J.A. and CUTLER, D.J., 2000. The hypothalamus and the regulation of energy of homeostasis: lifting the lid on a black box. The Proceedings of the Nutrition Society, vol. 59, no. 3, pp. 385-396. http://dx.doi.org/10.1017/ S0029665100000434. PMid:10997654. 